\title{
Illuminating the interrelated immune and endocrine adaptations after multiple exposures to short immobilization stress by in vivo blocking of IL-6
}

C. Smith, N. W. Wilson, A. Louw and K. H. Myburgh

Am J Physiol Regulatory Integrative Comp Physiol 292:1439-1447, 2007. First published Dec 14, 2006; doi:10.1152/ajpregu.00602.2006

You might find this additional information useful...

This article cites 68 articles, 28 of which you can access free at:

http://ajpregu.physiology.org/cgi/content/full/292/4/R1439\#BIBL

Updated information and services including high-resolution figures, can be found at: http://ajpregu.physiology.org/cgi/content/full/292/4/R1439

Additional material and information about American Journal of Physiology - Regulatory, Integrative and Comparative Physiology can be found at:

http://www.the-aps.org/publications/ajpregu

This information is current as of April 4, 2007 .

The American Journal of Physiology - Regulatory, Integrative and Comparative Physiology publishes original investigations that illuminate normal or abnormal regulation and integration of physiological mechanisms at all levels of biological organization, ranging from molecules to humans, including clinical investigations. It is published 12 times a year (monthly) by the American

Physiological Society, 9650 Rockville Pike, Bethesda MD 20814-3991. Copyright @ 2005 by the American Physiological Society. ISSN: 0363-6119, ESSN: 1522-1490. Visit our website at http://www.the-aps.org/. 


\title{
Illuminating the interrelated immune and endocrine adaptations after multiple exposures to short immobilization stress by in vivo blocking of IL-6
}

\author{
C. Smith, ${ }^{1}$ N. W. Wilson, ${ }^{1,2}$ A. Louw, ${ }^{2}$ and K. H. Myburgh ${ }^{1}$ \\ Departments of ${ }^{1}$ Physiological Sciences and ${ }^{2}$ Biochemistry, Stellenbosch University, Matieland, South Africa
}

Submitted 25 August 2006; accepted in final form 10 December 2006

Smith C, Wilson NW, Louw A, Myburgh KH. Illuminating the interrelated immune and endocrine adaptations after multiple exposures to short immobilization stress by in vivo blocking of IL-6. Am J Physiol Regul Integr Comp Physiol 292: R1439-R1447, 2007. First published December 14, 2006; doi:10.1152/ajpregu.00602.2006.— Intermittent psychological stress was induced in adult rats by $2 \mathrm{~h} /$ day of immobilization stress for 4 days, with or without blocking the function of IL- 6 by using an anti-IL- 6 antibody. Basal concentrations of serum corticosterone, IL-1 $\beta$, IL-6, and TNF- $\alpha$ were assessed $24 \mathrm{~h}$ after the last intervention, as were levels of glucocorticoid receptors (GR) and activities of glucocorticoid-inducible enzymes (tyrosine aminotransferase and glutamine synthetase) in muscle and liver. Whole blood cultures were used to assess both spontaneous and LPS-induced reactivity of peripheral blood mononuclear cells. Stress increased corticosterone concentration in a manner partially modulated by IL-6. Serum IL-1 $\beta$ concentration was downregulated during stress when IL-6 was blocked $(P<0.01)$. LPS-induced IL-6 secretion by peripheral blood mononuclear cells in vitro correlated positively with serum IL-1 $\beta$ concentration in antibody-treated groups, independently of stress $(R=0.70$ in nonstressed and $R=0.78$ in stressed rats; both $P<0.05$ ), whereas serum corticosterone concentration correlated positively with LPS-induced secretion of IL-6 only in control rats $(R=0.66 ; P<0.05)$. Reductions in liver GR levels indicated independent effects of stress $(34.5 \%)$ and anti-IL-6 antibody (16.7\%) and additive effects for both $(62.5 \%)$. Similar results are reported for vastus muscle. Conversely, stress increased tyrosine aminotransferase and glutamine synthetase activities in muscle and liver with a significant $(P<0.05)$ effect of anti-IL-6 antibody only seen in stressed livers. In conclusion, IL-6 plays a role in maintaining circulating IL-1 $\beta$ concentration after multiple exposures to stress, thus promoting a continued elevation of corticosterone release; in peripheral tissues, IL-6 antagonizes the effects of glucocorticoids, especially at the level of GR concentration.

corticosterone; glucocorticoid receptors; tyrosine aminotransferase; peripheral blood mononuclear cell function

ACUTE PSYCHOLOGICAL STRESS is known to activate the hypothalamic-pituitary-adrenal (HPA) axis, resulting in transiently increased release of inflammatory cytokines (28) and glucocorticoids (45). In contrast, multiple exposures to stress lead to adaptive responses in target tissues such as liver, skeletal muscle, and immune cells. These responses may be influenced by the severity of the stressor and the duration of the stress exposure. The endocrine and cytokine responses are known to be interrelated but are complex and still incompletely understood.

Human subjects with chronic mild psychological stress can be divided into those with low cortisol responses to stress (nonresponders) and those with high cortisol responses to stress (responders) (33). Serum IL-6 concentration is higher in

Address for reprint requests and other correspondence: C. Smith, Dept. of Physiological Sciences, Univ. of Stellenbosch, Private Bag X1, Matieland 7602, South Africa (e-mail: csmith@sun.ac.za). the nonresponders, illustrating the role of cortisol as a negative feedback mechanism to prevent an "overshoot" of the inflammatory response to stress, as was suggested in earlier reviews $(45,46)$. On the other hand, several experiments have highlighted the role of IL-6 as a stimulator of cortisol release by either directly acting on the adrenal gland $(19,52)$ or by upstream stimulation of the HPA axis $(40,72)$. Similarly, IL-6 is associated with greater bioavailability of cortisol via inhibition of cortisol-binding globulin synthesis (7). These results suggest a central role for IL-6 in the bidirectional communication between the cytokine and glucocorticoid systems in response to stress.

Although it is clear from the above that both cytokines and glucocorticoids are important links in the HPA axis response, the exact mechanisms and role players in the adaptive responses of the target tissues to multiple stress exposures are less clear.

The immune cell responses to stress differ between acute and chronic exposure. Acute social stress in rats was previously shown to depress $\mathrm{T}$ cell count after $2 \mathrm{~h}$ and to a lesser extent after $48 \mathrm{~h}$ of constant stress exposure (63). Also, the in vitro mitogen-induced $\mathrm{T}$ cell proliferative response followed the same pattern and was depressed after $2 \mathrm{~h}$ but not after $48 \mathrm{~h}$ of stress (63). However, an even longer exposure to stress (6 wk) impaired $\mathrm{T}$ cell-dependent antibody production in a murine model of chronic mild depression (61). The changes in $\mathrm{T}$ cell functional capacity reported in the above-mentioned study were not related to the circulating glucocorticoid concentration, which remained unchanged at the time points measured (61). This suggests either an increase in T cell sensitivity to stress hormones or an alternative mechanism.

Apart from their regulatory roles in the immune response, both glucocorticoids and IL-6 have been shown to have metabolic roles. Metabolic effects of glucocorticoids include, for example, the upregulation of gluconeogenesis via glucocorticoid-inducible enzymes such as glutamine synthetase (GS) and tyrosine aminotransferase (TAT), which have been shown to have increased activities in liver during stress $(35,50)$ and may therefore serve as downstream indicators of glucocorticoid action.

The biological effect of cortisol is mediated by the glucocorticoid receptor (GR) (37). Glucocorticoids can themselves regulate levels of GR (1). However, the exact effect of stress on GR levels is controversial. Some research groups reported decreased GR levels in response to increased circulating cortisol $(21,70)$, suggesting a mechanism to limit the prolonged effects of cortisol, whereas others reported increases in both

The costs of publication of this article were defrayed in part by the payment of page charges. The article must therefore be hereby marked "advertisement" in accordance with 18 U.S.C. Section 1734 solely to indicate this fact. 
the levels and activity of GR $(2,66)$. Given the importance of GR in the regulation of glucocorticoid action, this discrepancy warrants further investigation. Furthermore, NF-кB-mediated inflammation was recently reported to induce target tissue resistance to glucocorticoids by altering GR activity in the lungs (41), indicating interaction between mediators of inflammation and glucocorticoid action.

IL-6 has a known metabolic role in response to the stress of exercise (54), and a number of studies suggest that a bidirectional communication between IL- 6 and glucocorticoids in peripheral tissues is possible, although results reported are varied. On the one hand, IL-6 enhanced glucocorticoid action, e.g., by upregulation of GR in lymphoid and osteoblast-like cell lines $(3,13,56)$ and by increasing release of the acute phase proteins [haptoglobin (31) and $\alpha_{2}$-macroglobulin $(26,34)]$ in hepatoma cells. On the other hand, a series of in vivo $(25,64)$ and in vitro $(24,65)$ studies elucidated an antiglucocorticoid effect of IL-6. In adrenalectomized rats exposed to endotoxin treatment (elevating IL-6), dexamethasone-induced phosphoenolpyruvate carboxykinase activity was decreased. This was found to be the result of IL-6-mediated downregulation of hepatic GR.

Taking the above results into consideration, the modulation by IL-6 of glucocorticoid-induced responses occurs in many tissues and could be either repressing or enhancing the effect of the glucocorticoids. Alternatively, no cross-talk occurs, but IL-6 may have independent additive effects. The potential benefit of upregulating glucocorticoid-induced responses would be to inhibit inflammation, whereas a potential benefit of downregulation of glucocorticoid-induced responses would be to inhibit catabolic metabolism. Therefore, we hypothesize that the glucocorticoid-induced upregulation of metabolic genes would be moderated by IL-6 to prevent excessive catabolism, whereas the modulatory effect of IL-6 on the adrenal secretion of corticosterone would be additive to further promote an anti-inflammatory response.

Recently, the possibility of blocking the effects of one or another cytokine in the cascade of the inflammatory response has become possible by either the use of knockout models, e.g., an IL-6 knockout mouse model (71), or administration of antiserum or antibody, e.g., antibodies directed against IL-6 $(39,49)$. Such studies, although not close to in vivo physiological models of imposed stress, can illuminate our understanding of the major role players in these complex responses to stress or illness.

In a rat model of meningitis, treatment with anti-IL-6 antibodies resulted in a decreased immune response to the disease [fewer white blood cells (WBCs) in cerebrospinal fluid] (39), indicating a direct role for IL-6 in upregulation of WBC proliferation. In IL-6 knockout mice, TNF- $\alpha$ concentrations were higher after experimental endotoxemia (LPS injections) than in IL-6 intact mice (71). Because IL-1 $\beta$ is the primary stimulus for TNF- $\alpha$ production and is also known to be upstream of IL-6 secretion, this led to the conclusion that IL-6 normally limits the upregulation of TNF- $\alpha$ and possibly other proinflammatory cytokines. However, in the absence of other circulating immune and stress-endocrine measurements, the significance of this result is difficult to interpret.

Therefore, the aims of this study were to induce a condition of mild psychological stress in rats by multiple exposures to immobilization stress, while blocking the function of IL-6, to determine 1) the effect of IL- 6 on circulating concentrations of other proinflammatory cytokines in response to stress, 2) the effect of IL-6 on circulating glucocorticoid concentration, and 3) differences between IL-6-mediated modulation of stressinduced adaptive responses in target tissues (GR levels and activities of glucocorticoid-inducible enzymes in both liver and skeletal muscle and in vitro functional capacity of proinflammatory immune cells). To assess residual effects remaining evident at basal, nonacute time points, rats were killed $24 \mathrm{~h}$ after the final stressor.

\section{MATERIALS AND METHODS}

\section{Experimental Animals}

Forty male Wistar rats were used in this study. Rats were housed in standard rat cages and fed rat chow and tap water ad libitum. Temperature in the housing facility was controlled at $21^{\circ} \mathrm{C}$, and lights were set to a 12:12-h light-dark cycle (lights on at 7:00 AM). Rats were bought in from a breeding facility and allowed $3 \mathrm{wk}$ to acclimate before initiation of the study protocol, during which time they were handled and weighed once per day (7 times per wk) to accustom them to this procedure. The investigation conforms with the "Guide for the Care and Use of Laboratory Animals" published by the National Institutes of Health (NIH publication 85-23, revised 1996), and the study was approved by the Stellenbosch University Ethics Review Board.

\section{Preparation of Anti-IL-6 Antibody Treatments}

An antibody raised in goats immunized with purified Escherichia coli-derived recombinant rat IL-6 (AF506, R\&D Systems) was used as intervention treatment in this study. Lyophilized antibody $(100 \mu \mathrm{g})$ was reconstituted with $1 \mathrm{ml}$ of sterile PBS, according to manufacturer's instructions, to yield an antibody concentration of $0.1 \mathrm{mg} / \mathrm{ml}$. This stock solution was further diluted in sterile PBS to yield a final concentration of $2 \mu \mathrm{g} / \mathrm{ml}$, so that an injection of $0.5 \mathrm{ml} /$ day would result in a dose of $1 \mu \mathrm{g} \cdot \mathrm{rat}^{-1} \cdot \mathrm{day}^{-1}$ of anti-IL-6 antibody, in accordance with the manufacturer's indicated neutralization dosage, as well as with previous studies $(6,27)$. This solution was kept at $4^{\circ} \mathrm{C}$ for the duration of the protocol (stable for $1 \mathrm{mo}$ at this temperature, according to the manufacturer).

\section{Intervention}

Rats were divided into four experimental groups ( $n=10$ each): control + placebo $(\mathrm{CP})$, control + antibody $(\mathrm{CA})$, immobilization + placebo (IP), and immobilization + antibody (IA). Placebo rats (CP and IP) were injected intraperitoneally with $0.5 \mathrm{ml}$ of sterile isotonic saline once per day, and antibody rats (CA and IA) were injected intraperitoneally with $0.5 \mathrm{ml}$ of anti-IL-6 antibody, prepared as described above. In addition, immobilization groups (IP and IA) were subjected to immobilization stress for $2 \mathrm{~h}$ once per day, using the protocol described previously (62). Briefly, rats were individually confined in small Perspex cages $(6 \times 8 \times 18 \mathrm{~cm})$ designed for this purpose, which did not allow free movement. Both the injection treatment and immobilization stress protocols lasted 4 days, after which rats were killed by decapitation $24 \mathrm{~h}$ after the last intervention procedure, to exclude the acute response to the last intervention from being a confounding factor.

\section{Sample Collection}

Whole blood was collected by exsanguination, via a heparinized funnel, into one lithium heparin and one serum separation tube (SST) Vacutainer tube (BD Systems, Plymouth, UK). The heparinized blood was analyzed for total and differential WBC counts and mitogeninduced peripheral blood mononuclear cells (PBMC) IL-6 secretion in 
vitro. SST blood was centrifuged at $3,000 \mathrm{rpm}$ for $10 \mathrm{~min}$ at $0^{\circ} \mathrm{C}$, before being aliquoted and frozen at $-80^{\circ} \mathrm{C}$ for subsequent batch analysis of IL- $1 \beta$, TNF- $\alpha$, IL- 6 , and corticosterone concentrations.

In addition, skeletal muscle (gastrocnemius and vastus) and livers were dissected out within $5 \mathrm{~min}$ of decapitation. All samples were snap-frozen in liquid nitrogen and then stored at $-80^{\circ} \mathrm{C}$ until subsequent analysis for GR level and GS and TAT activities.

\section{Blood Analysis}

All analyses on fresh blood were performed within $3 \mathrm{~h}$ of collection. Heparinized blood $(500 \mu \mathrm{l})$ was decanted immediately into a 1.5-ml reaction vial (Eppendorf; Sigma) for determination of a total and differential WBC count, performed by automated analysis in a professional veterinary pathology laboratory (VetCare, Parow, South Africa). The rest of the blood was used to determine the ability of PBMCs in whole blood culture to secrete IL-6 in response to mitogen (E. coli LPS) stimulation, using an adaptation of a method used previously for investigations in human blood (55). Briefly, whole blood $(500 \mu \mathrm{l})$ was incubated in $2 \mathrm{ml}$ of RPMI 1640 medium (Highveld Biologicals) in one tube and in $2 \mathrm{ml}$ of RPMI 1640 medium containing E. coli LPS $(1.5 \mu \mathrm{g} / \mathrm{l})$ in another tube for $24 \mathrm{~h}$. All samples were then centrifuged, and the supernatant was used for determination of IL-6 concentration by ELISA (Biotrak RPN 2742; AEC Amersham Biosciences). IL- 6 concentration measured in the tube containing sample and medium only, was termed "spontaneous IL-6 secretion," whereas the difference between IL- 6 concentration in the LPS-containing tube and the spontaneous IL-6 secretion was termed "LPSinduced IL-6 secretion."

Commercially available ELISA kits were used for determination of serum IL-1 $\beta$ (Biotrak RPN 2743; AEC Amersham Biosciences), TNF- $\alpha$ (865.000.096; Diaclone), IL-6 (Biotrak RPN 2742; AEC Amersham Biosciences), and corticosterone (AC-14F1, Octeia; Immunodiagnostic Systems) concentrations.

\section{Determination of Muscle and Liver GR Levels by Binding Assay}

Liver and vastus muscle cytosols were prepared from homogenates with the use of modifications of the method previously described $(2,29,67)$. Briefly, to prepare liver cytosol, the same areas of each of the livers were thawed, weighed, cut into fine pieces, and homogenized (using an Ultra-turrax homogenizer) in cytosol buffer $A$ (10 mM Tris $\cdot \mathrm{HCl}, \mathrm{pH} 7.5$, containing $0.25 \mathrm{M}$ sucrose, $0.1 \mathrm{mM}$ PMSF, and 10 $\mu \mathrm{g} / \mathrm{ml}$ aprotinin) at $4{ }^{\circ} \mathrm{C}$ and at a tissue-to-buffer ratio of $1: 2(\mathrm{wt} / \mathrm{vol}$ ), e.g., $1 \mathrm{~g}$ of tissue was homogenized in $2 \mathrm{ml}$ of buffer. The homogenate was ultracentrifuged at $100,000 \mathrm{~g}$ for $1 \mathrm{~h}$ at $4^{\circ} \mathrm{C}$. The upper fatty layer was discarded, and the crude cytosol was treated with $100 \mu \mathrm{l}$ of dextran-coated charcoal (DCC; $3.75 \mathrm{~g}$ of charcoal and $0.375 \mathrm{~g}$ of dextran T-70 made up in $100 \mathrm{ml}$ of $10 \mathrm{mM}$ Tris $\cdot \mathrm{HCl}, \mathrm{pH} 7.5$ ) for 15 min at $4{ }^{\circ} \mathrm{C}$ to remove endogenous steroids. This was followed by a centrifugation step $\left(3,000 \mathrm{rpm}\right.$ for $10 \mathrm{~min}$ at $\left.4^{\circ} \mathrm{C}\right)$. The resulting clear supernatant was referred to as "liver cytosol." "Muscle cytosol" was prepared from both vastus muscles in a similar fashion to preparation of the liver cytosol, except that the cytosol buffer $A$ was replaced with cytosol buffer $B(10 \mathrm{mM}$ Tris $\cdot \mathrm{HCl}, \mathrm{pH} 7.5$, which contained $0.25 \mathrm{M}$ sucrose, $1.5 \mathrm{mM}$ EDTA, $10 \mathrm{mM}$ sodium molybdate, $5 \mathrm{mM}$ DTT, 10 $\mathrm{mM}$ monothioglycerol, $2 \mathrm{mM}$ PMSF, $10 \mu \mathrm{g} / \mathrm{ml}$ leupeptin, and 10 $\mu \mathrm{g} / \mathrm{ml}$ aprotinin). The protein concentration of the cytosols was determined by the Bradford assay (9).

Liver cytosols were diluted 1:20 in cytosol buffer $A$, whereas muscle cytosols were used undiluted in the binding assay. To determine GR binding capacity, cytosol $(250 \mu \mathrm{l})$ was incubated with $10 \mu \mathrm{l}$ of $400 \mathrm{nM}\left[{ }^{3} \mathrm{H}\right]$ dexamethasone (diluted in ethanol), in the presence of $10 \mu \mathrm{l}$ excess $(0.4 \mathrm{mM})$ unlabeled dexamethasone (nonspecific receptor binding) or ethanol (total receptor binding) and $130 \mu \mathrm{l}$ of cytosol buffer (buffer $A$ for liver and buffer $B$ for muscle) for $24 \mathrm{~h}$ at $4^{\circ} \mathrm{C}$. DCC $(100 \mu \mathrm{l})$ was added for $10 \mathrm{~min}$ at $4^{\circ} \mathrm{C}$ to separate free and GR-bound $\left[{ }^{3} \mathrm{H}\right]$ dexamethasone $(90 \mathrm{Ci} / \mathrm{mmol}$; Amersham Biosciences,
Athens, Greece) as previously described (8). DCC-containing samples were then centrifuged at $3,000 \mathrm{~g}$ for $10 \mathrm{~min}$ at $4{ }^{\circ} \mathrm{C}$. The supernatants $(350 \mu \mathrm{l})$ were collected into scintillation vials, $3 \mathrm{ml}$ of scintillation fluid (catalog no. 1004000; Zinsser Analytical) were added, and radioactivity was measured using a Beckman LS3801 scintillation counter. Specific receptor binding was determined as the difference between total receptor binding and nonspecific receptor binding. Specific receptor binding was normalized for protein content (expressed as fmol/mg protein). DCC efficiency for removal of unbound radioactive-labeled steroid was at least $95 \%$, and counting efficiency was typically $35 \%$ or higher, with $<10 \%$ ligand depletion.

\section{Tyrosine Aminotransferase Assay}

Liver and muscle cytosols were prepared as for the binding assay. Liver cytosols were diluted $1: 100$ in $\mathrm{K}_{2} \mathrm{HPO}_{4}$ buffer $(125 \mathrm{mM})$ containing $5 \mathrm{mg} / \mathrm{ml} \mathrm{BSA}, 1 \mathrm{mM}$ EDTA, and $1 \mathrm{mM}$ DTT, but muscle cytosols were used undiluted. TAT activity was determined according to a method described previously $(12,20,60)$. In short, TAT catalyzes the conversion of tyrosine to $p$-hydroxyphenylpyruvate (pHPP) in the presence of $\alpha$-ketoglutarate and pyridoxal-5' - phosphate. After incubation periods of $5,10,20$, and $30 \mathrm{~min}$ at $37^{\circ} \mathrm{C}, 10 \mathrm{~N} \mathrm{KOH}$ was added to catalyze the conversion of pHPP to oxalate and $p$-hydroxybenzaldehyde (pHBA). After $30 \mathrm{~min}$, the formation of pHBA was quantified spectrophotometrically by measurement of absorbance at $330 \mathrm{~nm}$. TAT activity was calculated by using a molar extinction coefficient of $19,900 \mathrm{M}^{-1} \cdot \mathrm{cm}^{-1}$ for pHBA (12). One unit of enzyme activity was defined as the quantity of enzyme that catalyzed the formation of 1 $\mathrm{mmol}$ of pHPP per minute at $37^{\circ} \mathrm{C}$ and was expressed relative to cytosol protein content.

\section{GS Assay}

GS activity was determined in cytosols from gastrocnemius muscle samples with a method described earlier $(42,43)$, which measures the GS-dependent formation from glutamine of $\gamma$-glutamyl hydroxamate, quantified spectrophotometrically by measurement of absorbance at $540 \mathrm{~nm}$ after $25 \mathrm{~min}$ of incubation at $37^{\circ} \mathrm{C}$. GS activity was calculated with a molar extinction coefficient of $1.08 \mathrm{M} / \mathrm{cm}$ (44) and was expressed relative to cytosol protein content.

\section{Statistical Analysis}

Effects of interventions were assessed by two-way ANOVA (control vs. immobilization and placebo vs. antibody), and differences between experimental groups were determined with Fisher's post hoc tests. Correlations between parameters measured were determined by Pearson's correlations (Statistica version 7; StatSoft). The level of significance was set at $P<0.05$.

\section{RESULTS}

\section{Body Mass}

Average percent change in body mass was calculated for days $1-4$ before the start of the intervention protocol, as well as for the 4 days of the intervention protocol (Fig. 1). Average percent change in body mass was similar in all groups during the 4 days before entry into the study, and groups had similar average body masses on day 1 of the intervention protocol (means \pm SE; CP: $519 \pm 18$, CA: $509 \pm 10$, IP: $517 \pm 15$, and IA: $498 \pm 22 \mathrm{~g})$. There was a main effect of stress on body mass $(P<0.00001)$. Both groups subjected to immobilization stress (IP and IA) lost a significantly greater percent body mass during the intervention protocol than their respective nonstressed groups (CP and CA) (Fig. 1). When comparing the two immobilized groups (IP and IA), there was no significant main effect of anti-IL-6 antibody treatment on the percent 


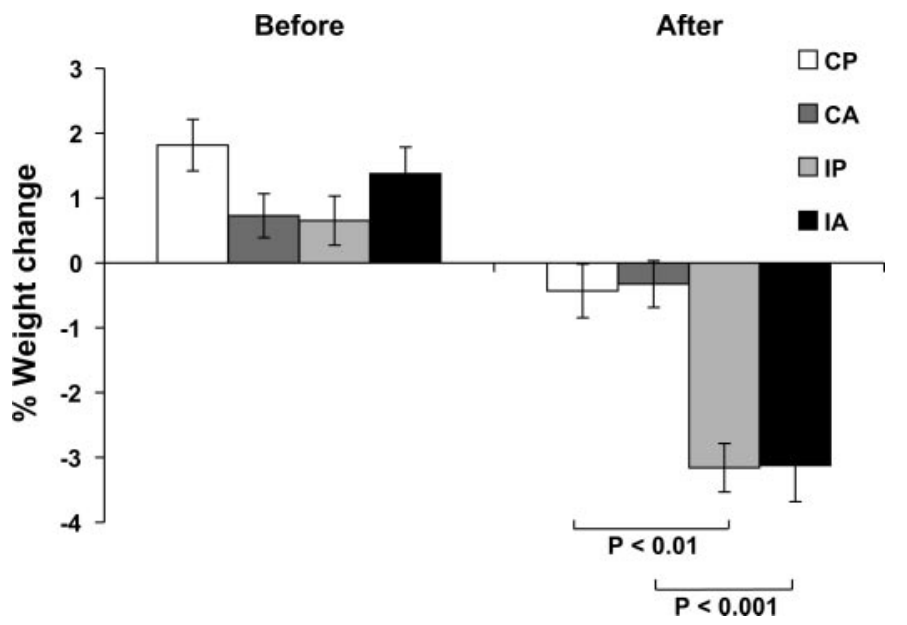

Fig. 1. Mean percent change in body mass for 4 days before the start of the intervention protocol vs. during the 4 days of the intervention protocol. Values are means $\pm \mathrm{SE}$. CP, control + placebo treated; CA, control + anti-IL-6 antibody treated; IP, immobilized + placebo treated; IA, immobilized + anti-IL-6 treated. $P$ values were obtained with Fisher's post hoc analysis.

change in body mass from day 1 of the stress intervention to death $(P=0.08)$.

\section{Responses Measured in Circulation}

Mean corticosterone concentration was significantly higher in IP vs. both CP and CA (Fig. 2). Although this increase tended to be ameliorated in IA, mean corticosterone concentration of IA was not significantly different from any other group.

IL-6 concentration was below the detectable level in all but four samples, and TNF- $\alpha$ was detectable in only two (different) samples. IL-1 $\beta$ concentration decreased during stress (Fig. 3) but only significantly so when the IL-6 antibody was administered.

\section{Target Tissue Responses}

PBMC functional response. Total and differential WBC counts were similar for all experimental groups (Table 1).

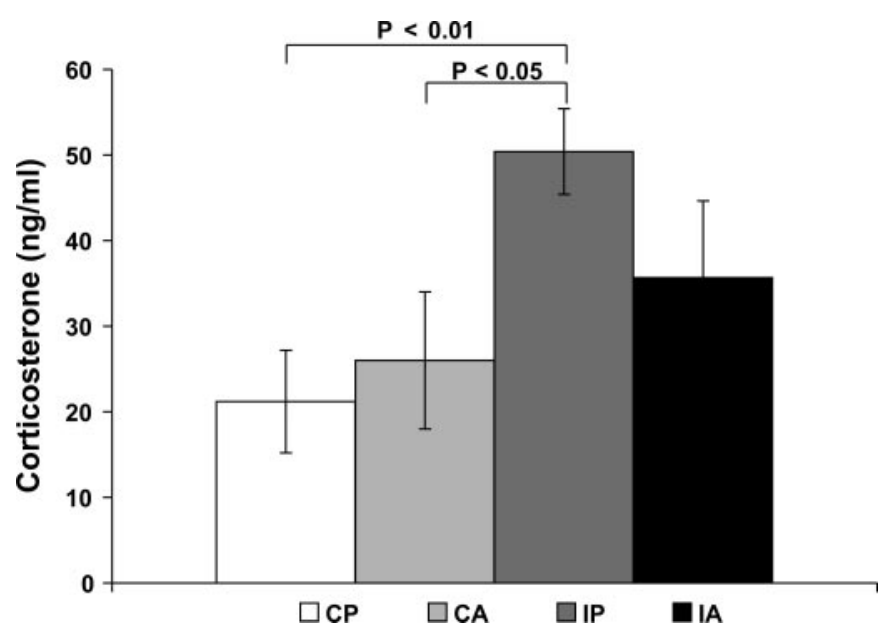

Fig. 2. Differences in serum corticosterone concentration between experimental groups. Values are means \pm SE. $P$ values were obtained with Fisher's post hoc analysis.

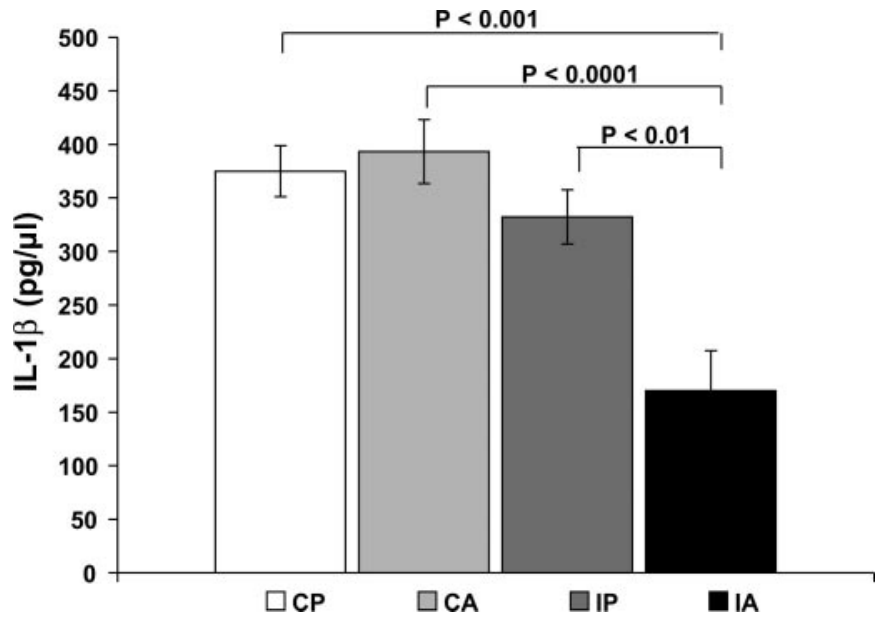

Fig. 3. Effect of anti-IL-6 treatment and/or immobilization stress on serum IL-1 $\beta$ concentrations. Values are means \pm SE. $P$ values were obtained with Fisher's post hoc analysis.

Although spontaneous in vitro IL-6 release by PBMCs was not influenced by the study protocol (Fig. 4A), treatment with anti-IL-6 antibody was associated with significantly increased LPS-induced IL-6 release from PBMCs after $24 \mathrm{~h}$ of incubation (Fig. 4B). Although the treatment effect was significant, post hoc analysis indicated a more robust difference in nonstressed groups, for both absolute LPS-induced IL-6 release (Fig. 4B) and IL-6 release expressed relative to PBMC count (CP: $31.0 \pm 8.1$, CA: $72.4 \pm 16.1$, IP: $31.8 \pm 16.9$, IA: $47.6 \pm$ $\left.15.8 \mathrm{pg} / \mathrm{cell} \times 10^{6}\right)$.

LPS-induced IL-6 secretion in vitro was positively correlated with serum IL-1 $\beta$ concentration in both antibody-treated groups (Table 2). Although serum corticosterone concentration was positively correlated with LPS-induced secretion of IL-6 in $\mathrm{CP}$, this relationship was lost after intervention with antibody, immobilization, or both (Table 2).

Metabolic tissue parameters. GR levels in both vastus muscle and liver were significantly downregulated in response to stress (Fig. 5). In addition, treatment with anti-IL-6 antibody significantly decreased GR levels in control and stressed animals. TAT activity was significantly upregulated in both the vastus muscle and liver in the stressed groups compared with controls (Fig. 6). Furthermore, TAT activity was higher in the antibody-treated groups than in the corresponding placebo groups, although only significantly so for the stressed group in the liver (Fig. 6). Although GS activity did not seem to be significantly influenced by anti-IL-6 antibody treatment, stress

Table 1. Total and differential WBC counts at death

\begin{tabular}{lcccc}
\hline \hline \multicolumn{1}{c}{ Parameter } & $\mathrm{CP}$ & $\mathrm{CA}$ & $\mathrm{IP}$ & $\mathrm{IA}$ \\
\hline WBCs, $\times 10^{9} / 1$ & $8.4 \pm 0.8$ & $9.8 \pm 0.4$ & $8.4 \pm 0.6$ & $7.8 \pm 0.4$ \\
Neutrophils, $\times 10^{9} / 1$ & $0.8 \pm 0.2$ & $0.9 \pm 0.2$ & $0.7 \pm 0.1$ & $1.0 \pm 0.3$ \\
Lymphocytes, & & & & \\
$\quad \times 10^{9} / 1$ & $7.2 \pm 0.7$ & $8.6 \pm 0.5$ & $7.3 \pm 0.6$ & $6.6 \pm 0.5$ \\
Monocytes, $\times 10^{9} / 1$ & $0.15 \pm 0.07$ & $0.15 \pm 0.05$ & $0.15 \pm 0.06$ & $0.10 \pm 0.05$ \\
\hline
\end{tabular}

Values are means $\pm \mathrm{SE}$. $\mathrm{CP}$, control + placebo; CA, control + placebo treated; IP, immobilized + placebo treated; IA, immobilized + anti-IL-6 treated; WBC, white blood cell. $P$ values were obtained with Fisher's post hoc analysis. 
A

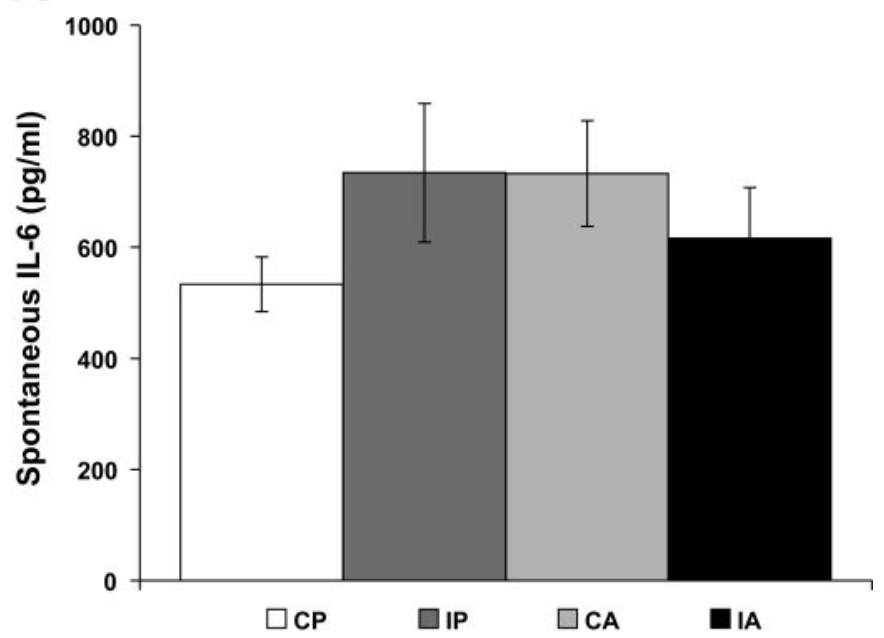

B

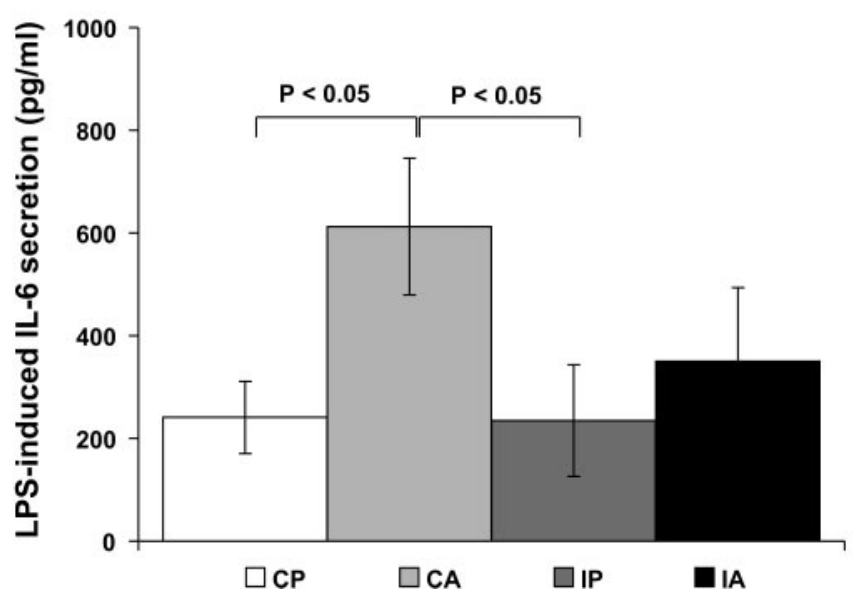

Fig. 4. Effect of in vivo anti-IL-6 treatment on spontaneous $(A)$ and mitogeninduced $(B)$ secretion of IL-6 by peripheral blood mononuclear cells in plasma-replaced blood culture, after $24 \mathrm{~h}$ of incubation. Values are means \pm SE. $P$ values were obtained with Fisher's post hoc analysis.

resulted in significantly increased GS activity in gastrocnemius muscle (Fig. 7).

\section{DISCUSSION}

No in vivo studies have investigated the effect of multiple exposures to psychological stress on cytokines in conjunction with endocrine parameters and with inclusion of GR analysis at the level of target tissues other than the central nervous system. The present study utilized two treatments (namely, anti-IL-6

Table 2. Correlations between LPS-induced IL-6 secretion by PBMCs in culture and serum IL-1 $\beta$ and corticosterone concentration

\begin{tabular}{|c|c|c|c|c|}
\hline & $\mathrm{CP}$ & $\mathrm{CA}$ & IP & IA \\
\hline $\begin{array}{l}\text { Serum IL- } 1 \beta \text { concentration, } \mathrm{pg} / \mu \mathrm{l} \\
\text { vs. LPS-induced IL- } 6, \mathrm{pg} / \mathrm{ml}\end{array}$ & -0.18 & $0.70^{*}$ & -0.07 & $0.78 *$ \\
\hline $\begin{array}{l}\text { Serum corticosterone concentration, } \mathrm{ng} / \mathrm{ml} \\
\text { vs. LPS-induced IL-6, pg/ml }\end{array}$ & $0.66^{*}$ & -0.49 & -0.12 & 0.14 \\
\hline
\end{tabular}

Values are $R$ values. PBMCs, peripheral blood mononuclear cells. $* P<0.05$.
A

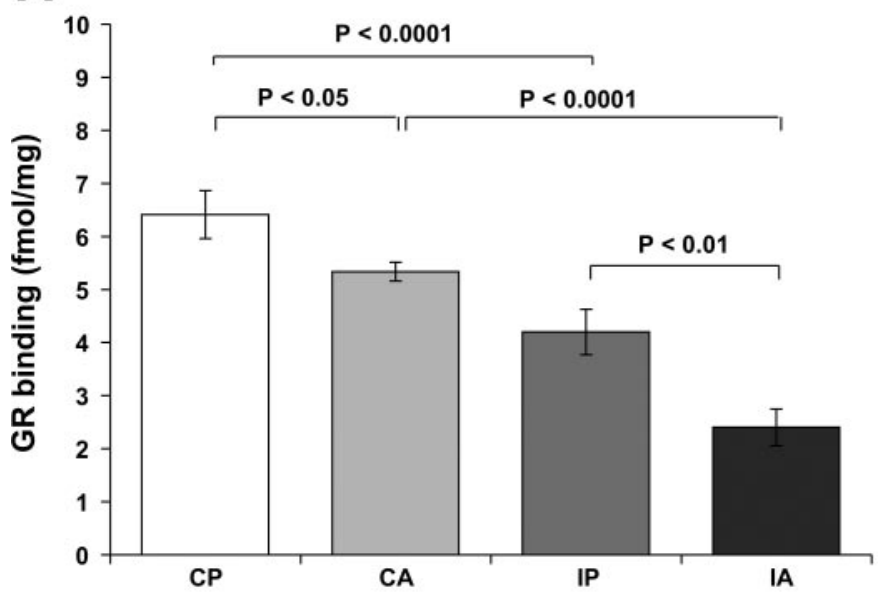

B

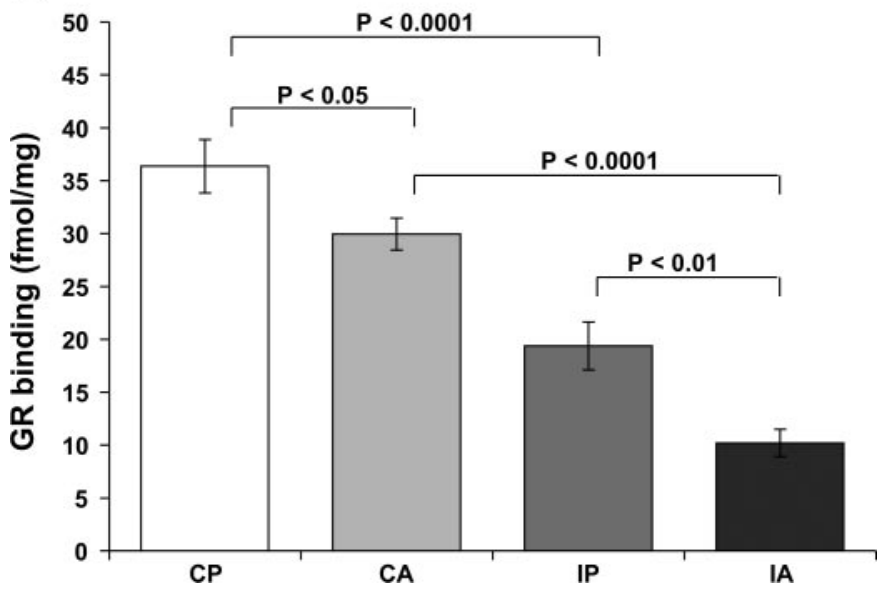

Fig. 5. Effects of immobilization stress and anti-IL-6 antibody treatment on glucocorticoid receptor (GR) levels (as determined by binding assay) in vastus muscle $(A)$ and liver $(B)$ of male Wistar rats. Values are means \pm SE. $P$ values were obtained with Fisher's post hoc analysis.

antibody and multiple exposures to immobilization) to clearly define four conditions: no intervention, an effect of absence of IL-6 alone, an effect of stress with an adequate capacity for an IL-6 response, and an effect of absence of IL- 6 in the presence of stress. Together, these data illuminate the role of IL-6 under basal unstressed conditions and in the presence of psychological stress.

\section{Circulating Parameters}

Similar to earlier results by our group and other research groups $(14,45,62)$, repeated exposures to immobilization stress resulted in significantly increased basal serum corticosterone concentrations compared with control groups. However, a novel finding is that, in the IL-6-antibody-treated stressed group, this increase was attenuated (Fig. 2). These results suggest that the full-blown corticosterone response is dependent, at least in part, on IL-6 during multiple exposures to stress. These results are in agreement with studies reporting a stimulatory effect of IL- 6 on the HPA axis at different levels, including the pituitary and adrenal glands, which results in an increased corticosterone secretion $(36,47,72)$. However, the 
A

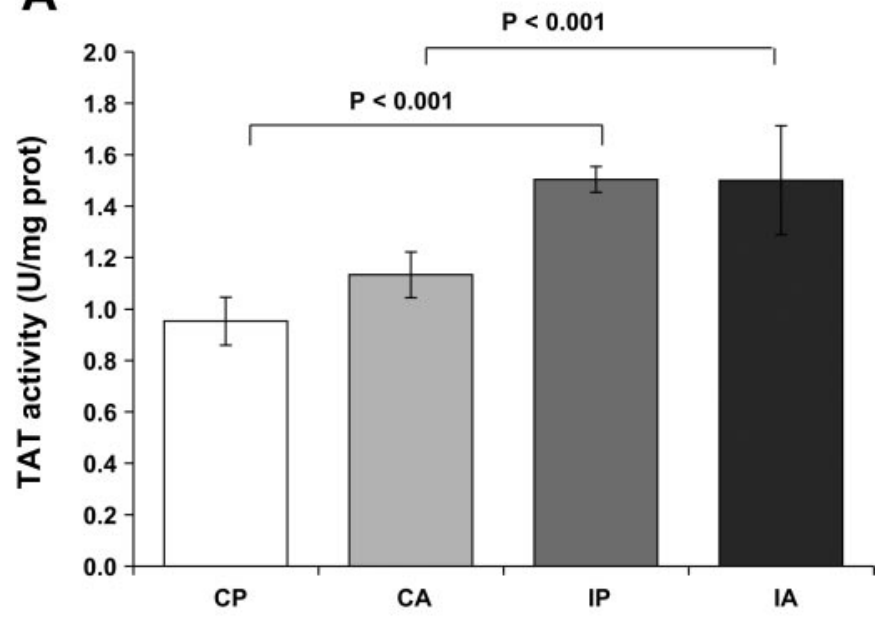

B

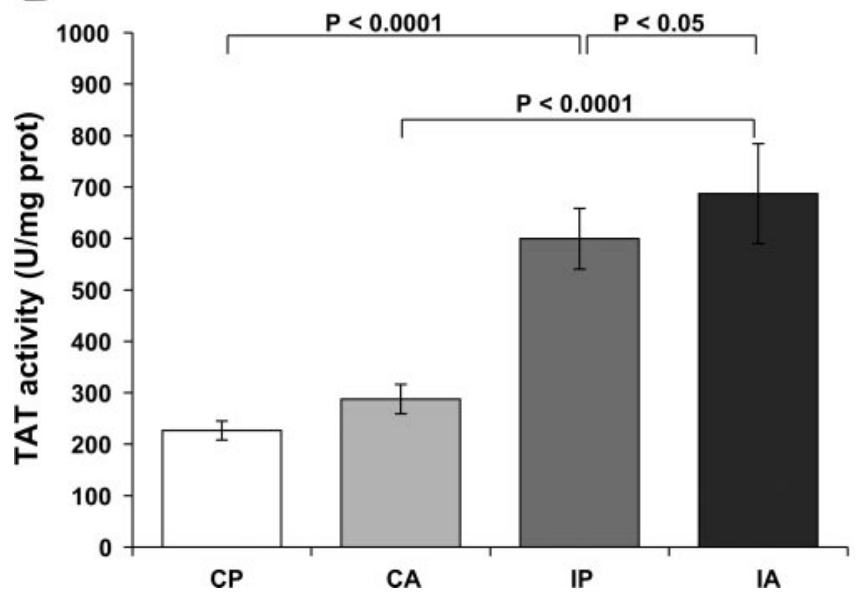

Fig. 6. Effects of stress and/or anti-IL-6 antibody treatment on tyrosine aminotransferase (TAT) activity (determined by the nonenzymatic conversion of $p$-hydroxyphenylpyruvate to $p$-hydroxybenzaldehyde) in vastus muscle $(A)$ and liver $(B)$ of male Wistar rats. Values are means \pm SE. $P$ values were obtained with Fisher's post hoc analysis.

results of the present study are not in agreement with a previous study utilizing anti-IL-6-treated mice, which suggested that acute restraint stress activates the HPA axis independently of IL-6 (49). There may have been a few factors that differed between their study and the present one, for example, a much higher basal corticosterone concentration even in their control group, varied individual corticosterone responses in their stressed groups, and small sample size.

Circulating corticosterone provides negative feedback to attenuate IL-1 $\beta$ secretion (28). The negative feedback provided by the elevated corticosterone concentrations in IP in the present study (Fig. 2) appeared to be sufficient in these rats for their IL-1 $\beta$ concentrations to be similar to their controls (CP) under basal conditions despite prior exposures to stress (Fig. 3). A novel finding in the present study was that blocking of IL-6 is associated with a significant decrease in IL-1 $\beta$ under basal conditions only in the stressed group (Fig. 3). This finding was unexpected because the corticosterone levels in IA were less elevated at the time of death than that for IP (Fig. 2) so that less negative feedback might have been expected. One explanation for this finding is that the system in IA is lacking an agent that normally promotes IL-1 $\beta$ secretion. We therefore suggest that positive feedback by IL- 6 on IL- $1 \beta$ secretion occurs with stress and that the role is to partially negate the downregulatory effect of corticosterone on IL-1 $\beta$. This suggestion is supported by an earlier in vitro finding of IL-6-stimulated upregulation of IL-1 $\beta$ mRNA in human T cells (51). However, because this suggestion is based in part on the assumption of transiently elevated IL-6, which was no longer evident under the basal conditions at death, it can only be proven definitively in vivo, by assessment of multiple time points after an acute stressor when IL-6 will also be sufficiently elevated to be easily detectable. Nonetheless, we have shown that in this system it is necessary to both perturb the system (intervening with stress exposure) and block the particular agent of interest, to unravel the complexity of the interactions in play.

Both IL- 6 and TNF- $\alpha$ were nondetectable at rest $24 \mathrm{~h}$ after multiple exposures to a mild stressor, but this finding is not inexplicable. IL-6 levels have been reported by others to respond rapidly, rising within $15 \mathrm{~min}$ of exposure to psychological stress $(11,68)$ and to return to baseline levels within 12-24 h after exposure to acute moderate stress, albeit in other models $(48,71)$. TNF- $\alpha$ concentration is also known to be tightly regulated, rising within $30 \mathrm{~min}$ of exposure to stress, with an in vivo half-life of $<2 \mathrm{~h}(16,18,38)$. In the present study, rats were killed $24 \mathrm{~h}$ after the last stress exposure. Even with chronic stress, the duration of exposure that resulted in upregulation of basal IL- 6 concentration in the circulation of human subjects was in excess of $6 \mathrm{yr}$ (30). The protocol used in the present study was only 4 days of intermittent exposure to a mild stressor and is not analogous to the condition of chronically elevated circulating proinflammatory cytokines, but rather represents a model of the early phase of adaptation to stress. Unfortunately, because the protocol used in the present study allowed for blood sampling at only one time point $(24 \mathrm{~h}$ after the last intervention), no conclusions can be made with regard to transient changes in circulating cytokine levels.

\section{Target Tissue Responses}

The interventions used in this study did not significantly affect total or differential WBC counts (Table 1). Absolute

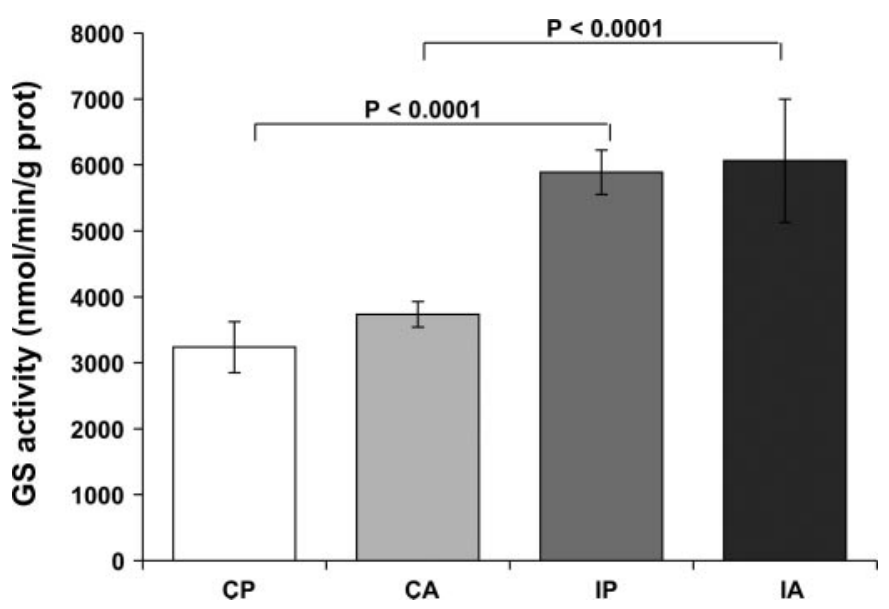

Fig. 7. Comparison of gastrocnemius muscle glutamine synthetase (GS) activity (determined by measurement of formation of $\gamma$-glutamylhydroxamate from glutamate, ADP, and hydroxylamine) between the experimental groups. prot, Protein. Values are means \pm SE. $P$ values were obtained with Fisher's post hoc analysis. 
total WBC and lymphocyte counts were slightly higher, and the neutrophil count was lower, than those reported earlier in Long-Evans rats subjected to either no stress or to 2 or $48 \mathrm{~h}$ of social stress (63). Because these immune cell counts did not respond to stress in either study, the differences in cell counts between the two studies are most likely due to interstrain differences. However, considering the reported decrease in peripheral node lymphocyte function after acute inescapable tail shock (17), an unchanged total WBC or lymphocyte cell count does not necessarily imply unchanged cell function. Therefore, functional test results should also be considered in a comprehensive evaluation of the immune response to stress.

PBMCs in culture exhibited a similar ability to spontaneously secrete IL-6 during incubation in all groups. This suggests that neither 4 days of immobilization stress nor shortterm blocking of IL-6 is sufficiently severe to result in a change in basal excitation of mononuclear cells in the absence of a specific stimulant. However, a main effect of anti-IL-6 antibody treatment was a significant increase in mitogen-induced IL-6 secretion in the combined antibody-treated groups compared with the combined placebo groups (main effect: $P<$ 0.05 ), with no independent or interactive effect of immobilization. The result of no effect of immobilization is in accordance with previous reports of unchanged mitogen-induced lymphocyte proliferation rate in rats subjected to social stress (63). There are three possible explanations for the main effect of the anti-IL-6 antibody. First, if the replacement of blood plasma by culture medium in the assay procedure did not successfully remove all of the antibody from the cell culture, it is possible that the antibody present initially bound to the IL-6 secreted in response to LPS. This would result in an increased cytokine secretion due to lack of early negative feedback by IL-6 on cell function. Second, an alternative explanation is that, if anti-IL-6 antibody became membrane bound and was not washed out by plasma replacement, it may have prevented negative feedback throughout the assay time period. Third, blocking of IL-6 may have caused adaptation of PBMCs to render them more sensitive to mitogen stimulation, so that stimulation resulted in excess cytokine secretion by these cells. The fact that mitogen-induced IL-6 release in vitro was positively correlated with serum IL-1 $\beta$ concentrations in the antibody-treated groups only suggests that the proposed effect on PBMCs may have been mediated before culture by IL-1 $\beta$. It also argues against the finding being an artifact of residual antibody in the assay procedure, since the correlation was with serum IL-1 $\beta$ and not with in vitro mitogen-induced PBMCsecreted IL- $1 \beta$.

Chronic stress is commonly associated with body mass loss in both human $(4,32,73)$ and animal models (58). Although the mechanisms have not been fully elucidated, either TNF- $\alpha$ or glucocorticoids or both may be possible mediators of this process. Even IL-6 has recently been shown to have a direct effect of inducing skeletal muscle atrophy by downregulation of intracellular anabolic signaling (23). Because the present study used intermittent immobilization to induce stress, the possibility exists that this short duration of decreased mechanical loading may have caused muscle atrophy and consequently body mass loss. However, other studies that reported evidence of severe disuse-induced muscle atrophy in rats used more severe models of continuous immobilization $(53,58)$. The 2 $\mathrm{h} /$ day of immobilization in the present study occurred during the rats' sleep cycle and was unlikely to have altered their daily physical activity. Rather, we present other evidence of significant glucocorticoid effects, arguing in favor of circulating atrophy-inducing factors predominating in the observed loss of body mass.

The finding in the present study of a $38-47 \%$ decrease in GR levels in response to stress is in agreement with previous reports that illustrated a stress-induced decrease of between 25 and $50 \%$ in GR levels in the liver and brain $(50,59)$. The GRbinding capacities reported in the present study are lower than those reported by other groups in the liver (e.g., $36 \pm 3$ $\mathrm{fmol} / \mathrm{mg}$ protein) and muscle (e.g., $6 \pm 0.5 \mathrm{fmol} / \mathrm{mg}$ protein) $(2,67)$. Interstrain differences in the glucocorticoid response to stress (5) or differences in the techniques used to determine GR levels may explain differences in absolute binding capacities.

The IL-6 antibody treatment caused a significant downregulation of GR binding capacity in both skeletal muscle and liver in the present study, suggesting that the normal effect of IL-6 in these peripheral tissues is either an independent upregulatory effect on GR levels or an antagonizing effect on a glucocorticoid-induced downregulation of its own receptors. In vitro, IL-6 upregulates GR levels in Kaposi sarcoma (22), as well as in lymphoid, monocytoid, and hepatoma cell lines (56). In addition, IL- 6 antibody administration has also been shown to significantly decrease GR number in osteoblast cell lines, abolishing the upregulatory effect of IL-6 (13). However, the present study is the first to provide proof of this effect of IL-6 on GR levels in vivo by use of an anti-IL-6 antibody. Furthermore, the finding that GR levels are lower in the IA vs. the IP group in both the liver and muscle, whereas corticosterone levels are attenuated in the IA group vs. the IP group, suggests that this effect of IL-6 is not mediated via circulating glucocorticoids. We propose that future studies should investigate an intracellular cross talk.

Increases in TAT activity after only mild stress reported in the present study is in agreement with previous findings after more extreme interventions, such as glucocorticoid administration $(15,57)$, indicating that this enzyme is even more sensitive to stress than previously shown. The finding reported here of a further increase in liver TAT activity during stress, in the anti-IL-6 antibody-treated group, suggests an inhibitory role of IL-6 on this glucocorticoid-inducible enzyme. This result provides in vivo support for a recent, similar finding in rat fetal hepatoma cells in culture (74).

The nearly twofold increase in GS activity in stressed groups, compared with their respective control groups, is in agreement with the findings of an earlier study of intermittent hypoxic stress in Wistar rats (69). However, the finding that GS activity seemed to be independent of IL-6, especially given the finding that TAT activity seemed to be directly inhibited by IL-6 in the presence of stress, is more difficult to explain. However, it is in line with previous studies that also failed to show an effect of IL-6 on GS activity in murine astrocytes (10).

In conclusion, the present study illustrates that IL-6 plays a role in modulating the effect of glucocorticoids at systemic and peripheral levels. The present results clearly indicate that this modulating effect is to antagonize the effects of corticosterone. Therefore, during multiple exposures to mild stress, IL-6 plays a role in maintenance of the IL-1 $\beta$ and corticosterone concentrations, reducing the effect of negative feedback by corticosterone. In peripheral tissues, IL-6 reduces the effects of corti- 
costerone by limiting downregulation of GR levels in both muscle and liver, as well as preventing full-blown upregulation of activity of a glucocorticoid-inducible enzyme in the liver. This antagonistic cross talk is reminiscent of the well-known downregulatory effect of endogenous or exogenous glucocorticoids on proinflammatory cytokines and their actions. The authors further hypothesize that the brake provided by IL-6 in the periphery may limit an overshoot of the deleterious endocrine responses of tissues to stress. This presents a finer control of homeostasis than would be present without this dual system of reciprocal control.

\section{GRANTS}

Funding was provided by the South African Medical Research Council and the National Research Foundation of South Africa.

\section{REFERENCES}

1. Alexandrova M, Farkas P. Stress-induced changes of glucocorticoid receptor in rat liver. J Steroid Biochem Mol Biol 42: 493-498, 1992.

2. Al Mohaisen M, Cardounel A, Kalimi M. Repeated immobilization stress increases total cytosolic glucocorticoid receptor in rat liver. Steroids 65: 8-15, 2000.

3. Angeli A, Dovio A, Sartori ML, Masera RG, Ceoloni B, Prolo P, Racca S, Chiappelli F. Interactions between glucocorticoids and cytokines in the bone microenvironment. Ann NY Acad Sci 966: 97-107, 2002.

4. Anker SD, Ponikowski P, Varney S, Chua TP, Clark AL, WebbPeploe KM, Harrington D, Kox WJ, Poole-Wilson PA, Coats AJ. Wasting as independent risk factor for mortality in chronic heart failure. Lancet 349: 1050-1053, 1997.

5. Armario A, Gavalda A, Marti J. Comparison of the behavioural and endocrine response to forced swimming stress in five inbred strains of rats. Psychoneuroendocrinology 20: 879-890, 1995.

6. Arruda JL, Sweitzer S, Rutkowski MD, DeLeo JA. Intrathecal anti-IL-6 antibody and $\mathrm{IgG}$ attenuates peripheral nerve injury-induced mechanical allodynia in the rat: possible immune modulation in neuropathic pain. Brain Res 879: 216-225, 2000.

7. Bartalena L, Hammond GL, Farsetti A, Flink IL, Robbins J. Interleukin-6 inhibits corticosteroid-binding globulin synthesis by human hepatoblastoma-derived (Hep G2) cells. Endocrinology 133: 291-296, 1993.

8. Beato M, Feigelson P. Glucocorticoid-binding proteins of rat liver cytosol. I. Separation and identification of the binding proteins. J Biol Chem 247: 7890-7896, 1972.

9. Bradford MM. A rapid and sensitive method for the quantitation of microgram quantities of protein utilizing the principle of protein-dye binding. Anal Biochem 72: 248-254, 1976.

10. Chao CC, Hu S, Tsang M, Weatherbee J, Molitor TW, Anderson WR, Peterson PK. Effects of transforming growth factor-beta on murine astrocyte glutamine synthetase activity. Implications in neuronal injury. J Clin Invest 90: 1786-1793, 1992.

11. Derijk RH, Boelen A, Tilders FJ, Berkenbosch F. Induction of plasma interleukin- 6 by circulating adrenaline in the rat. Psychoneuroendocrinology 19: 155-163, 1994.

12. Diamondstone TI. Assay of tyrosine transaminase activity by conversion of $p$-hydroxyphenylpyruvate to $p$-hydroxybenzaldehyde. Anal Biochem 16: 395-401, 1966.

13. Dovio A, Masera RG, Sartori ML, Racca S, Angeli A. Autocrine upregulation of glucocorticoid receptors by interleukin-6 in human osteoblastlike cells. Calcif Tissue Int 69: 293-298, 2001.

14. Dronjak S, Gavrilovic L, Filipovic D, Radojcic MB. Immobilization and cold stress affect sympatho-adrenomedullary system and pituitary-adrenocortical axis of rats exposed to long-term isolation and crowding. Physiol Behav 81: 409-415, 2004.

15. DuBois DC, Xu ZX, McKay L, Almon RR, Pyszcznski N, Jusko WJ. Differential dynamics of receptor down-regulation and tyrosine aminotransferase induction following glucocorticoid treatment. J Steroid Biochem Mol Biol 54: 237-243, 1995.

16. Feldman AM, Combes A, Wagner D, Kadakomi T, Kubota T, Li YY, McTiernan C. The role of tumor necrosis factor in the pathophysiology of heart failure. J Am Coll Cardiol 35: 537-544, 2000.

17. Fleshner M, Bellgrau D, Watkins LR, Laudenslager ML, Maier SF. Stress-induced reduction in the rat mixed lymphocyte reaction is due to macrophages and not to changes in $\mathrm{T}$ cell phenotypes. $J$ Neuroimmunol 56: 45-52, 1995.

18. Fotheringham JA, Mayne MB, Grant JA, Geiger JD. Activation of adenosine receptors inhibits tumor necrosis factor- $\alpha$ release by decreasing TNF-alpha mRNA stability and p38 activity. Eur J Pharmacol 497: 87-95, 2004

19. Franchimont D, Bouma G, Galon J, Wolkersdorfer GW, Haidan A, Chrousos GP, Bornstein SR. Adrenal cortical activation in murine colitis. Gastroenterology 119: 1560-1568, 2000.

20. Granner DK, Tomkins GM. Tyrosine aminotransferase (rat liver). Method Enzymol 17 633-637, 1970.

21. Grasso G, Lodi L, Lupo C, Muscettola M. Glucocorticoid receptors in human peripheral blood mononuclear cells in relation to age and to sport activity. Life Sci 61: 301-308, 1997.

22. Guo WX, Antakly T, Cadotte M, Kachra Z, Kunkel L, Masood R, Gill P. Expression and cytokine regulation of glucocorticoid receptors in Kaposi's sarcoma. Am J Pathol 148: 1999-2008, 1996.

23. Haddad F, Zaldivar F, Cooper DM, Adams GR. IL-6-induced skeletal muscle atrophy. J Appl Physiol 98: 911-917, 2005.

24. Hill MR, Stith RD, McCallum RE. Human recombinant IL-1 alters glucocorticoid receptor function in Reuber hepatoma cells. J Immunol 141: $1522-1528,1988$.

25. Hill MR, Stith RD, McCallum RE. Monokines mediate decreased hepatic glucocorticoid binding in endotoxemia. J Leukoc Biol 41: 236241, 1987.

26. Hocke GM, Barry D, Fey GH. Synergistic action of interleukin-6 and glucocorticoids is mediated by the interleukin- 6 response element of the rat alpha 2 macroglobulin gene. Mol Cell Biol 12: 2282-2294, 1992.

27. Hogan D, Morrow JD, Smith EM, Opp MR. Interleukin-6 alters sleep of rats. J Neuroimmunol 137: 59-66, 2003.

28. Ishikawa I, Kitamura H, Kimura K, Saito M. Brain interleukin-1 is involved in blood interleukin-6 response to immobilization stress in rats. Jpn J Vet Res 49: 19-25, 2001.

29. Kalimi M, Hubbard JR. Development of an exchange assay for cytosolic glucocorticoid receptors using the synergistic effects of molybdate plus dithiothreitol. Endocrinology 113: 1161-1163, 1983.

30. Kiecolt-Glaser JK, Preacher KJ, MacCallum RC, Atkinson C, Malarkey WB, Glaser R. Chronic stress and age-related increases in the proinflammatory cytokine IL-6. Proc Natl Acad Sci USA 100: 9090-9095, 2003.

31. Kim H, Baumann H. The carboxyl-terminal region of STAT3 controls gene induction by the mouse haptoglobin promoter. J Biol Chem 272: 14571-14579, 1997.

32. Kotler DP. Wasting syndrome: nutritional support in HIV infection. AIDS Res Hum Retroviruses 10: 931-934, 1994.

33. Kunz-Ebrecht SR, Mohamed-Ali V, Feldman PJ, Kirschbaum C, Steptoe A. Cortisol responses to mild psychological stress are inversely associated with proinflammatory cytokines. Brain Behav Immun 17: 373383, 2003.

34. Kunz D, Zimmermann R, Heisig M, Heinrich PC. Identification of the promoter sequences involved in the interleukin- 6 dependent expression of the rat alpha 2-macroglobulin gene. Nucleic Acids Res 17: 1121-1138, 1989.

35. Labow BI, Souba WW, Abcouwer SF. Glutamine synthetase expression in muscle is regulated by transcriptional and posttranscriptional mechanisms. Am J Physiol Endocrinol Metab 276: E1136-E1145, 1999.

36. Leonard BE. The HPA and immune axes in stress: the involvement of the serotonergic system. Eur Psychiatry 20, Suppl 3: S302-S306, 2005.

37. Listwak SJ, Gold PW, Whitfield HJ Jr. The human mineralocorticoid receptor gene promoter: its structure and expression. J Steroid Biochem Mol Biol 58: 495-506, 1996.

38. Mann DL. Stress activated cytokines and the heart. Cytokine Growth Factor Rev 7: 341-354, 1996.

39. Marby D, Lockhart GR, Raymond R, Linakis JG. Anti-interleukin-6 antibodies attenuate inflammation in a rat meningitis model. Acad Emerg Med 8: 946-949, 2001.

40. Mastorakos G, Chrousos GP, Weber JS. Recombinant interleukin-6 activates the hypothalamic-pituitary-adrenal axis in humans. J Clin Endocrinol Metab 77: 1690-1694, 1993.

41. Meduri GU, Muthiah MP, Carratu P, Eltorky M, Chrousos GP. Nuclear factor-кB- and glucocorticoid receptor alpha- mediated mechanisms in the regulation of systemic and pulmonary inflammation during sepsis and acute respiratory distress syndrome. Evidence for inflamma- 
tion-induced target tissue resistance to glucocorticoids. Neuroimmunomodulation 12: 321-338, 2005.

42. Meister A. Glutamine synthetase from mammalian tissues. Methods Enzymol 113: 185-199, 1985.

43. Minet R, Villie F, Marcollet M, Meynial-Denis D, Cynober L. Measurement of glutamine synthetase activity in rat muscle by a colorimetric assay. Clin Chim Acta 268: 121-132, 1997.

44. Montanini B, Betti M, Marquez AJ, Balestrini R, Bonfante P, Ottonello S. Distinctive properties and expression profiles of glutamine synthetase from a plant symbiotic fungus. Biochem J 373: 357-368, 2003.

45. Munck A, Guyre PM. Glucocorticoid physiology, pharmacology and stress. Adv Exp Med Biol 196: 81-96, 1986.

46. Munck A, Guyre PM, Holbrook NJ. Physiological functions of glucocorticoids in stress and their relation to pharmacological actions. Endocr Rev 5: 25-44, 1984.

47. Muramami N, Fukata J, Tsukada T, Kobayashi H, Ebisui O, Segawa H, Muro S, Imura H, Nakao K. Bacterial lipopolysaccharide-induced expression of interleukin-6 messenger ribonucleic acid in the rat hypothalamus, pituitary, adrenal gland, and spleen. Endocrinology 133: $2574-$ 2578, 1993.

48. Northoff H, Weinstock C, Berg A. The cytokine response to strenuous exercise. Int J Sports Med 15, Suppl 3: S167-S171, 1994.

49. Nukina H, Sudo N, Komaki G, Yu X, Mine K, Kubo C. The restraint stress-induced elevation in plasma interleukin- 6 negatively regulates the plasma TNF- $\alpha$ level. Neuroimmunomodulation 5: 323-327, 1998.

50. Omrani GR, Rosner W, Loeb JN. Induction of hepatic tyrosine aminotransferase by physiological stress: relation to endogenous glucocorticoid secretion and cytosol receptor depletion. J Steroid Biochem 13: 719-722, 1980.

51. Panzer S, Madden M, Matsuki K. Interaction of IL-1 beta, IL-6 and tumour necrosis factor-alpha (TNF- $\alpha$ ) in human $\mathrm{T}$ cells activated by murine antigens. Clin Exp Immunol 93: 471-478, 1993.

52. Path G, Bornstein SR, Spath-Schwalbe E, Scherbaum WA. Direct effects of interleukin-6 on human adrenal cells. Endocr Res 22: 867-873, 1996.

53. Pattison JS, Folk LC, Madsen RW, Booth FW. Selected contribution: identification of differentially expressed genes between young and old rat soleus muscle during recovery from immobilization-induced atrophy. J Appl Physiol 95: 2171-2179, 2003.

54. Pedersen BK, Steensberg A, Schjerling P. Exercise and interleukin-6. Curr Opin Hematol 8: 137-141, 2001.

55. Pool EJ, Johaar G, James S, Petersen I, Bouic P. The detection of pyrogens in blood products using an ex vivo whole blood culture assay. J Immunoassay 19: 95-111, 1998.

56. Rakasz E, Gal A, Biro J, Balas G, Falus A. Modulation of glucocorticosteroid binding in human lymphoid, monocytoid and hepatoma cell lines by inflammatory cytokines interleukin (IL)-1 $\beta$, IL-6 and tumour necrosis factor (TNF)- $\alpha$. Scand J Immunol 37: 684-689, 1993.

57. Ramakrishnan R, DuBois DC, Almon RR, Pyszczynski NA, Jusko WJ. Pharmacodynamics and pharmacogenomics of methylprednisolone during 7-day infusions in rats. J Pharmacol Exp Ther 300: 245-256, 2002.

58. Sakakima H, Yoshida Y, Sakae K, Morimoto N. Different frequency treadmill running in immobilization-induced muscle atrophy and ankle joint contracture of rats. Scand J Med Sci Sports 14: 186-192, 2004.
59. Sapolsky RM, Krey LC, McEwen BS. Stress down-regulates corticosterone receptors in a site-specific manner in the brain. Endocrinology 114: 287-292, 1984.

60. Schacke H, Schottelius A, Docke WD, Strehlke P, Jaroch S, Schmees N, Rehwinkel H, Hennekes H, Asadullah K. Dissociation of transactivation from transrepression by a selective glucocorticoid receptor agonist leads to separation of therapeutic effects from side effects. Proc Natl Acad Sci USA 101: 227-232, 2004.

61. Silberman DM, Ayelli-Edgar V, Zorrilla-Zubilete M, Zieher LM, Genaro AM. Impaired T-cell dependent humoral response and its relationship with $\mathrm{T}$ lymphocyte sensitivity to stress hormones in a chronic mild stress model of depression. Brain Behav Immun 18: 81-90, 2004.

62. Smith C, Myburgh KH. Treatment with Sutherlandia frutescens ssp. microphylla alters the coticosterone response to chronic intermittent immobilization stress in rats. South African J Sci 100 229-232, 2004.

63. Stefanski V, Engler H. Effects of acute and chronic social stress on blood cellular immunity in rats. Physiol Behav 64: 733-741, 1998.

64. Stith RD, McCallum RE. Down regulation of hepatic glucocorticoid receptors after endotoxin treatment. Infect Immun 40: 613-621, 1983.

65. Stith RD, McCallum RE, Hill MR. Effect of interleukin-6/interferonbeta 2 on glucocorticoid action in rat hepatoma cells. J Steroid Biochem 34: 479-481, 1989.

66. Sun X, Fischer DR, Pritts TA, Wray CJ, Hasselgren PO. Expression and binding activity of the glucocorticoid receptor are upregulated in septic muscle. Am J Physiol Regul Integr Comp Physiol 282: R509-R518, 2002.

67. Sun YN, McKay LI, DuBois DC, Jusko WJ, Almon RR. Pharmacokinetic/pharmacodynamic models for corticosteroid receptor down-regulation and glutamine synthetase induction in rat skeletal muscle by a receptor/gene-mediated mechanism. J Pharmacol Exp Ther 288: 720$728,1999$.

68. Takaki A, Huang QH, Somogyvari-Vigh A, Arimura A. Immobilization stress may increase plasma interleukin-6 via central and peripheral catecholamines. Neuroimmunomodulation 1: 335-342, 1994.

69. Vats P, Mukherjee AK, Kumria MM, Singh SN, Patil SK, Rangnathan S, Sridharan K. Changes in the activity levels of glutamine synthetase, glutaminase and glycogen synthetase in rats subjected to hypoxic stress. Int J Biometeorol 42: 205-209, 1999.

70. Webster JI, Sternberg EM. Role of the hypothalamic-pituitary-adrenal axis, glucocorticoids and glucocorticoid receptors in toxic sequelae of exposure to bacterial and viral products. J Endocrinol 181: 207-221, 2004.

71. Xing Z, Gauldie J, Cox G, Baumann H, Jordana M, Lei XF, Achong MK. IL-6 is an anti-inflammatory cytokine required for controlling local or systemic acute inflammatory responses. J Clin Invest 101: 311-320, 1998.

72. Zhou D, Kusnecov AW, Shurin MR, DePaoli M, Rabin BS. Exposure to physical and psychological stressors elevates plasma interleukin 6: relationship to the activation of hypothalamic-pituitary-adrenal axis. Endocrinology 133: 2523-2530, 1993.

73. Zinna EM, Yarasheski KE. Exercise treatment to counteract protein wasting of chronic diseases. Curr Opin Clin Nutr Metab Care 6: 87-93, 2003.

74. Zvibel I, Brill S, Kariv R, Traister A, Golan T, Chebath J, Halpern Z, Revel M, Oren R. Chimeric molecule IL-6/soluble IL-6 receptor is a potent mitogen for fetal hepatocytes. J Cell Physiol 200: 245-252, 2004. 